\title{
Removal of Prymnesium parvum (Haptophyceae) and its toxins using clay minerals
}

\author{
Mario R. Sengco ${ }^{\mathrm{a}, *}$, Johannes A. Hagström ${ }^{\mathrm{b}}$, Edna Granéli ${ }^{\mathrm{b}}$, \\ Donald M. Anderson $^{\mathrm{a}}$ \\ ${ }^{a}$ Biology Department, MS 32, Woods Hole Oceanographic Institution, Woods Hole, MA 02543 USA \\ ${ }^{\mathrm{b}}$ Department of Biology and Environmental Science, University of Kalmar, Barlastgatan 1, 39182 Kalmar, Sweden
}

Received 19 March 2004; received in revised form 30 April 2004; accepted 8 May 2004

\begin{abstract}
Laboratory experiments were conducted to examine the ability of several clay minerals from Sweden to remove the fish-killing microalga, Prymnesium parvum Carter, from suspension. In their commercial form (i.e. after incineration at $400^{\circ} \mathrm{C}$ ), seawater slurries (salinity $=26$ ) of the three minerals tested were generally ineffective at removing $P$. parvum from culture within a range of 0.01 to $0.50 \mathrm{~g} / \mathrm{L}$, and after $2.5 \mathrm{~h}$ of flocculation and settling. Dry bentonite (SWE1) displayed the highest removal efficiency (RE) at $17.5 \%$, with $0.50 \mathrm{~g} / \mathrm{L}$. Illite (SWE3) averaged only $7.5 \%$ RE between 0.10 to $0.50 \mathrm{~g} / \mathrm{L}$, while kaolinite (SWE2) kept the cells suspended instead of removing them. Brief mixing of the clay-cell suspension after SWE1 addition improved RE by a factor of 2.5 (i.e. $49 \%$ at $0.50 \mathrm{~g} / \mathrm{L}$ ), relative to no mixing. The addition of polyaluminum chloride (PAC, at $5 \mathrm{ppm}$ ) to $0.50 \mathrm{~g} / \mathrm{L} \mathrm{SWE} 1$ also improved RE to $50 \%$ relative to SWE1 alone, but only minor improvements in RE were seen with SWE2 and SWE2 combined with PAC. In further experiments, P. parvum grown in NP-replete conditions were removed in greater numbers than cells in $\mathrm{N}$ - or P-limited cultures, at $0.10-0.25 \mathrm{~g} / \mathrm{L}$ of SWE1 and $5 \mathrm{ppm}$ PAC. With $0.50 \mathrm{~g} / \mathrm{L}, \mathrm{RE}$ converged at $40 \%$ for all three culture conditions. The toxin concentration of NP-replete cultures decreased from 24.2 to $9.2 \mu \mathrm{g} / \mathrm{mL}$ (60\% toxin RE) with $0.10-0.50 \mathrm{~g} / \mathrm{L}$ SWE1 treatment and $5 \mathrm{ppm}$ PAC. A strong correlation was found between cell and toxin RE $\left(r^{2}=0.995\right)$. For $\mathrm{N}$-limited cultures, toxin RE ranged between 21 and $87 \%$ with the same clay/PAC concentrations, although the correlation between cell and toxin removal was more moderate $\left(r^{2}=0.746\right)$ than for NP-replete conditions. Interestingly, the toxin concentration within the clay-cell pellet increased dramatically after treatment, suggesting that clay addition may stimulate toxin production in $\mathrm{N}$-stressed cells. For P-limited cultures, toxin concentration also decreased following clay/PAC treatment (i.e. $36 \%$ toxin RE), but toxin removal was poorly correlated to cell removal $\left(r^{2}=0.462\right)$. To determine whether incineration affected SWE1's removal ability, a sample of its wet, unprocessed form was tested. The RE of wet bentonite (SWE4) was slightly better than that of SWE1 (31\% versus $17 \%$, respectively, at $0.50 \mathrm{~g} / \mathrm{L}$ ), but when $5 \mathrm{ppm}$ PAC was added, RE increased from 10 to $64 \%$ with $0.05 \mathrm{~g} / \mathrm{L}$ of SWE4, and increased further to $77 \%$ with $0.50 \mathrm{~g} / \mathrm{L}$. There were no significant differences in RE among NP-replete, N-limited and P-limited cultures using PAC-treated SWE4. Finally, RE varied with $P$. parvum concentration, reaching a maximum level at the lowest cell concentration $\left(1 \times 10^{3}\right.$ cells $\left./ \mathrm{mL}\right): 100 \%$ RE with 0.10 and $0.50 \mathrm{~g} / \mathrm{L} \mathrm{SWE} 4+5 \mathrm{ppm}$ PAC. RE dropped as cell concentration increased to $1 \times 10^{4}$ and $5 \times 10^{4}$ cells $/ \mathrm{mL}$, but rose again when concentration increased to $1 \times 10^{5}$ cells $/ \mathrm{mL}$, the concentration used routinely for the removal experiments above. Based on these results, SWE4 with PAC was the most effective mineral sample against $P$. parvum. Overall, these
\end{abstract}

\footnotetext{
* Corresponding author. Tel.: +1 508289 2749; fax: +1 5084572027.

E-mail address: msengco@whoi.edu (M.R. Sengco).
} 
studies demonstrated that clay flocculation can be effective at removing $P$. parvum and its toxins only under certain treatment conditions with respect to cell concentration, clay type and concentration, and physiological status.

(C) 2004 Elsevier B.V. All rights reserved.

Keywords: Prymnesium parvum; Clay minerals; Control; Toxins; HABs

\section{Introduction}

Prymnesium parvum Carter (Haptophyceae) is a toxic algal species commonly found in low salinity lakes (e.g. in Israel), and in the mesohaline waters of the Baltic Sea. With its production of toxins known collectively as prymnesins, $P$. parvum has been recognized as a potent fish-killing organism, affecting both wild and reared finfish (Komarovsky, 1951; Holmquist and Willém, 1993; Igarashi et al., 1996; Lindholm et al., 1999). Several studies have also shown that prymnesins are allelopathic against bacteria, other phytoplankton and potential grazers (Granéli and Johansson, 2001, 2003a, 2003b; Tillmann, 2003; Fistarol et al., 2003). Therefore, P. parvum and its cogeners have been considered among the most harmful species in these waters, especially towards finfish and bivalves (Moestrup, 1994), and may cause serious ecological and economic impacts to fisheries, recreational water use, and coastal ecosystems (Valkanov, 1964; Edvardsen and Paasche, 1998).

Given the impacts of this species, it seems prudent to investigate practical strategies to manage their blooms, including methods that directly target the organisms (i.e. bloom control). Recently, several workers have demonstrated the utility of common clay to control harmful algal blooms (HAB), by physically removing the causative organisms from the water column, through flocculation and settling (Shirota, 1989; Yu et al., 1994; Na et al., 1996; Sengco et al., 2001; Yu et al., in press). Operationally, clays are finely divided inorganic particles that are $<2 \mu \mathrm{m}$ in size. Mineralogically, materials referred to as clays belong to a specific class of hydrous aluminum silicates with layered, crystalline structures (Grim, 1953; Swartzen-Allen and Matijevic, 1974). Examples include kaolinite, montmorillonite (or bentonite), vermicullite, brucite, and illite. Generally, cell removal is thought to occur through mutual, rapid flocculation between clay and algal particles, leading to the for- mation of progressively larger aggregates that settle quickly through the water column, and further entrain cells during their descent (Yu et al., 1994; Sengco et al., 2001). Alternatively, Archambault et al. (2003) proposed that cells are removed when clay minerals on algal surfaces affect the viability and motility of cells, leading to settling. Clay flocculation has been tested in the laboratory for several algal species such as Noctiluca scintillans (Yu et al., 1994), Karenia brevis (Sengco et al., 2001), Cochlodinium polykrikoides (Na et al., 1996), Aureococcus anophagefferens (Yu et al., in press), Heterocapsa triquetra (Archambault et al., 2003) and Heterosigma akashiwo (Rensel et al., in press). These studies showed that the efficiency of cell removal varied with the type of mineral used, clay concentration, and cell concentration. For brackish water species, Avnimelech et al. (1982) and Soballe and Threlkeld (1988) found that cell removal depended on the ionic strength (i.e. $\mathrm{NaCl}$ or $\mathrm{CaCl}_{2}$ concentration) of the medium, as well as the type of cations in the system. For species that tolerate a wide range of salinities, there is limited information on how the effectiveness of clay flocculation would be affected when applied over salinity gradients. In one study, the removal efficiency of Pfiesteria piscicida was reduced by half as salinity increased from 0 to 30 (Sengco, unpublished data). Although there have been attempts to use models of flocculation theory to elucidate the mechanism of clay-cell flocculation, and to predict clays' effectiveness against a given species, these models remain incomplete (Sengco, 2001). Hence, selecting the most effective clay for a given species must be determined empirically, not by predictions or extrapolations based simply on the morphological, physiological or taxonomic similarities among species tested or environmental conditions (e.g. salinity, $\mathrm{pH}$, temperature).

The first study to use clay against $P$. parvum in culture was done by Hagström and Granéli (in press). Experiments showed that $100 \%$ of $P$. parvum can be removed within $72 \mathrm{~h}$ with $4 \mathrm{~g} / \mathrm{L}$ of Florida phosphatic 
clay, a sample consisting of smectite (i.e. montmorillonite), carbonate fluorapatite, and various other minerals, combined with $5 \mathrm{ppm}$ of polyaluminum chloride (PAC), a chemical flocculant. An $84 \%$ removal efficiency (RE) was achieved in $6 \mathrm{~h}$ at lower dosages. Experiments with nutrient-limited cultures showed that RE increased as the cells became more nutrient stressed. Lastly, the study also demonstrated the ability of phosphatic clay to remove $P$. parvum toxins. While these studies illustrated the potential utility of clay control in general, the phosphatic clay used was not commonly found in Europe. Moreover, the loading rates were much higher than those in other studies. Likewise, the time wherein cell removal reached maximum levels was much longer than in previous studies.

The objectives of this study were (i) to test a variety of locally available Swedish clays to determine their removal ability against Prymnesium parvum in culture, and (ii) to compare the removal of P. parvum grown under nutrient replete and stressed conditions. We predicted that bentonites would be most effective, as this mineral had been shown in earlier studies to be effective against a broad range of algal species, due to their ability to expand in water, and to develop strong surface charge (Avnimelech et al., 1982; Shirota, 1989; Na et al., 1996; Sengco et al., 2001). Larger particle size would theoretically increase the rate of particle collisions, while a stronger surface charge would lead to a greater likelihood of particle adhesion on contact, both of these leading to higher flocculation rates overall. On the other hand, kaolinites would be less effective as they do not swell when wetted, and have a much lower charge density than bentonites. Finally, we predicted that the removal ability of illites, brucites and vermicullites would lie between bentonites and kaolinites, as their mineralogical and chemical properties are intermediate to bentonites and kaolinites. Cell removal was determined for a range of clay concentrations and dispersal methods. Tests were also conducted to determine whether the use of PAC would improve removal. Also, the clays' ability to remove toxins was also tested. After the most effective clays and dispersal methods were determined, additional experiments were conducted to further examine the effect of cell concentration and culture conditions on RE.

\section{Materials and methods}

\subsection{Cultures}

Non-axenic P. parvum (KAC 39, Kalmar Algal Collection, Department of Biology and Environmental Science, University of Kalmar) were grown in 10-L batch cultures using filtered and autoclaved $\left(121^{\circ} \mathrm{C}\right)$ Baltic surface seawater (salinity $=6.2$ ), adjusted to a salinity of 26 with $\mathrm{NaCl}$. $P$. parvum were grown under three nutrient conditions: $\mathrm{N}$-limited $(\mathrm{N}: \mathrm{P}=4: 1$, $\left.16 \mu \mathrm{M} \mathrm{NO}^{3-}+4 \mu \mathrm{MPO}_{4}{ }^{3-}\right)$, P-limited $(\mathrm{N}: \mathrm{P}=80: 1$, $\left.80 \mu \mathrm{M} \mathrm{NO}^{3-}+1 \mu \mathrm{M} \mathrm{PO}_{4}{ }^{3-}\right)$ and NP-replete $(\mathrm{N}: \mathrm{P}$ $\left.=16: 1,58 \mu \mathrm{M} \mathrm{NO}^{3-}+3.63 \mu \mathrm{M} \mathrm{PO}_{4}{ }^{3-}\right)$. The cultures were kept at $17 \pm 1{ }^{\circ} \mathrm{C}$, under a light intensity of $120 \mu \mathrm{E} /\left(\mathrm{m}^{2} \mathrm{~s}\right.$ ) (cool white fluorescent tubes Philips TLD 36W/830), with a 16:8-h light:dark cycle. Duplicate samples were taken daily at 09:00 hours $\pm 1 \mathrm{~h}$, and enumerated within $30 \mathrm{~min}$ using a Coulter particle counter (Elzone 282 Particle Analyzer) or a flow cytometer (FACSCalibur, Becton Dickinson, Franklin Lakes, NJ, USA). Flow cytometer counts were calibrated with microscope counts, using an inverted microscope (Nikon Diaphot), according to the method of Utermöhl (1958) after fixation with acid Lugol solution. The cell removal experiments were performed when the nutrient-limited cultures reached stationary growth phase, and when the nutrient-replete culture reached exponential growth phase.

\subsection{Clay minerals}

Three different samples of clay minerals (SWE1, SWE2 and SWE3) were obtained from two Swedish companies (Table 1). To meet European Union regulations, the minerals had been incinerated $\left(>400^{\circ} \mathrm{C}\right)$ to eliminate organisms and other contaminants prior to dry export. The particle size composition of all three samples ranged from 0.1 to $2 \mu \mathrm{m}$. Slurries were prepared by dispersing the dry clay in $0.20 \mu \mathrm{m}$ filtered seawater (salinity $=26$ ) and allowed to equilibrate overnight.

\subsection{Removal experiments}

SWE1, SWE2 and SWE3 were tested at the Tvärminne Zoological Station in Finland. Experiments began by calibrating a Turner fluorometer (Model 
Table 1

Swedish clays tested against the fish-killing species, Prymnesium parvum Carter

\begin{tabular}{|c|c|c|c|c|c|}
\hline Code & Product name & Designation & Mineral composition & Size cut-off & Supplier \\
\hline SWE1 & Cedesorb VR1 & Dry bentonite & $>85 \%$ Bentonite, $3 \%$ quartz & $<1 \mathrm{~mm}$ & AB CDM, Gothenburg, Sweden \\
\hline SWE2 & Polwhite E Powder & Kaolinite & $\begin{array}{l}83 \% \text { Kaolinite, } 14 \% \text { mica, } 2 \% \\
\text { feldspar }<1 \% \text { quartz }\end{array}$ & $<1 \mathrm{~mm}$ & AB CDM, Gothenburg, Sweden \\
\hline SWE3 & No name & Illite & $\begin{array}{l}35 \% \text { Illite, } 25 \% \\
\text { smectite/vermiculite, } 20 \% \text { quartz, } \\
10 \% \text { feldspa } 5 \% \text { mica, } 5 \% \text { kaolinite }\end{array}$ & $<2 \mathrm{~mm}$ & BARA Mineraler, Bara, Sweden \\
\hline SWE4 & No name & Wet bentonite & $>85 \%$ Bentonite, $3 \%$ quartz & $<2 \mathrm{~mm}$ & BARA Mineraler, Bara, Sweden \\
\hline
\end{tabular}

10-AU, Turner Designs, Sunnyvale, California, USA) for in vivo fluorescence against Coulter cell counts of each $P$. parvum culture. Thirty milliliters of the NP-replete culture (at $1.9 \times 10^{5}$ cells $/ \mathrm{mL}$ ) were placed into triplicate sets of $50-\mathrm{mL}$ polypropylene centrufuge tubes. To each triplicate, $10 \mathrm{~mL}$ of clay slurry was added dropwise over the surface using an air displacement pipet. Note that slurries of each clay were made such that $10 \mathrm{~mL}$ added to the $30-\mathrm{mL}$ culture would yield the following final concentrations: $0.01,0.025$, $0.050,0.10,0.25$ and $0.50 \mathrm{~g} / \mathrm{L}$. For controls without clay, $10 \mathrm{~mL}$ of filtered seawater was added in the same manner. The tubes were placed in the culture room for $2.5 \mathrm{~h}$. Afterwards, the supernatants (here defined as the upper $28 \mathrm{~mL}$ above the clay/cell pellet) were transferred to clean tubes and mixed well. Then, $6 \mathrm{~mL}$ were taken to determine the final cell concentration by in vivo fluorescence. RE was calculated following Sengco et al. (2001):

$$
\begin{aligned}
\% \mathrm{RE}= & {[1-(\text { final fluorescence }} \\
\text { sample } & / \\
& \text { final fluorescence } \\
\text { control } & )] \times 100
\end{aligned}
$$

The final fluorescence of the control after $2.5 \mathrm{~h}$ was used in the calculation to account for cell loss due to sinking.

In parallel studies, the experiment above was repeated with two slight modifications to the protocol. For the first modification, the centrifuge tubes were vortexed by hand for about $5 \mathrm{~s}$ after the clay slurry (SWE1 only) was added to the culture. In theory, this step was added in order to promote collisions between Prymnesium cells and mineral particles, and to distribute the clay more evenly throughout the volume. The tubes were then placed upright in racks, and incubated for $2.5 \mathrm{~h}$ in the culture room undisturbed as before.
For the second modification, the chemical flocculant PAC (Superfloc 9001, Cytec Industries, Carmel, IN, USA), was added to the clay-cell suspension to enhance the clay's adhesiveness towards the cells, and thereby improve RE. A working solution of PAC was prepared such that $3 \mathrm{~mL}$ added to $27 \mathrm{~mL}$ of culture $\left(2.11 \times 10^{5}\right.$ cells $\left./ \mathrm{mL}\right)$ and $10 \mathrm{~mL}$ of clay slurry would yield $5 \mathrm{ppm}$ final concentration. First, the PAC solution was added dropwise to the culture and incubated for $30 \mathrm{~min}$ at room temperature. Then, the clay slurry was added to the surface, and the suspension was incubated for $2.5 \mathrm{~h}$ without mixing. The final clay concentrations were $0.01,0.025,0.050,0.10,0.25$ and $0.50 \mathrm{~g} / \mathrm{L}$. For PAC-only controls, $3 \mathrm{~mL}$ of PAC solution was added to $27 \mathrm{~mL}$ of culture, followed by $10 \mathrm{~mL}$ of filtered seawater (no clay). For controls without PAC and clay, $13 \mathrm{~mL}$ of seawater was added to $27 \mathrm{~mL}$ of culture. All three dry clays were tested.

\subsection{Nutrient-limited cultures and toxin analysis}

Based on the screening process above, SWE1 with PAC yielded the highest RE at the lowest clay concentration. Hence, SWE1 was subjected to further experiments, along with the protocol modification that included 5 ppm PAC additions.

At the start of the experiment, samples were taken from each culture for cell counts (Coulter counter) and determination of initial toxicity. P. parvum cells were filtered onto pre-combusted $\left(450{ }^{\circ} \mathrm{C}\right)$ Whatman GF/C glass fiber filters. The filters were then frozen at $-20^{\circ} \mathrm{C}$ for toxicity tests (see below). For the removal experiment, SWE1 and 5 ppm PAC were added to NP-replete, N-limited and P-limited cultures $\left(1.2 \times 10^{5}\right.$ cells $\left./ \mathrm{mL}\right)$ at $0,0.10,0.25$, and $0.50 \mathrm{~g} / \mathrm{L}$ of clay. After $2.5 \mathrm{~h}$, the RE was determined as previously 
described. The remaining supernatant $(22 \mathrm{~mL})$ and the clay-cell pellets (in $12 \mathrm{~mL}$ ) were filtered onto pre-combusted Whatman GF/C glass fiber filters and frozen. Later, all of the filters were thawed and extracted in the dark with $2 \mathrm{~mL}$ of methanol at room temperature overnight. The extracts were then subjected to the haemolysis tests of Simonsen and Moestrup (1997) with modifications by Hagström and Granéli (in press). First, the extracts were placed in 96-well microplates (Nunc Intermed, Denmark) in concentrations ranging from 4 to $50 \%$ of the algal extract in isotonic phosphate buffer (IPB) to a final volume of $5 \mu \mathrm{L}$. To this, $200 \mu \mathrm{L}$ of horse blood (5\% in IPB, obtained from the Swedish National Veterinary Institute) was then added. The plates were incubated in the dark at room temperature for $60 \mathrm{~min}$, after which they were centrifuged at $3000 \mathrm{rpm}$ for $5 \mathrm{~min}$ (Beckman Allegra ${ }^{\mathrm{TM}}$ 21). Finally, the supernatants were transferred into a new 96-well Costar ${ }^{\circledR}$ microplate, and the absorbance of the solution was measured at $540 \mathrm{~nm}$ using a spectrophotometer (FLUO Star Model 403, bmg Lab Technologies). Saponin (Sigma S-2149) in IPB (0-80\%) was used as a reference to generate a standard haemolytic curve. Each toxicity test was done in duplicate. The results were expresed in saponin equivalents ( $\mathrm{SE}$, at $\mathrm{mg} / \mathrm{mL}$ ) according to Simonsen and Moestrup (1997).

\subsection{Experiments with SWE4 (wet bentonite)}

To examine the effect of incineration and drying on the removal ability of Swedish clays, a sample of raw, unprocessed clay (SWE4, Table 1) was obtained and tested at the University of Kalmar in Sweden. The sample was provided in a freshwater slurry form. The percentage solid content was determined by drying pre-weighed aliquots of the suspension in an oven $\left(100^{\circ} \mathrm{C}\right)$ overnight, then dividing the dry weight by the wet weight multiplied by 100 . Working slurries of SWE4 were prepared by diluting the stock suspension with seawater (salinity $=26$ ).

Removal experiments were again performed as previously described, first without PAC, then with $5 \mathrm{ppm}$ PAC, against NP-replete cultures $\left(1.9 \times 10^{5}\right.$ cells $\left./ \mathrm{mL}\right)$. The final clay concentrations were $0,0.01,0.05,0.10$, and $0.50 \mathrm{~g} / \mathrm{L}$. Next, the removal ability of the clay was tested against $\mathrm{N}$ - and P-limited cultures. Finally, cell removal was determined at lower $P$. parvum con- centrations (P-limited culture): $1 \times 10^{3}, 1 \times 10^{4}$, and $5 \times 10^{4}$ cells $/ \mathrm{mL}$.

\section{Results}

\subsection{Clay screening}

Overall, the three incinerated clays (SWE1, SWE2 and SWE3) added without mixing and PAC were ineffective at removing $P$. parvum from culture within the range of concentrations tested (Fig. 1). The highest RE was $17.5 \pm 4.2 \%$ for SWE1 bentonite at $0.50 \mathrm{~g} / \mathrm{L}$. Cell removal by SWE1 was close to zero when clay concentration was $<0.10 \mathrm{~g} / \mathrm{L}$. In fact, several values were negative. Negative RE's were also seen with SWE2 kaolinite (Fig. 1B). In addition, suspensions with SWE2 remained turbid the longest among the three clays tested. Cultures treated with SWE3 illite remained turbid for shorter time than that of SWE2, but longer than SWE1 (Fig. 1C). The RE of SWE3 quickly saturated at approximately $7.5 \%$ for most of the concentration range, and is the second most effective mineral after SWE1. SWE2 was the least effective overall.

Mixing the clay-cell suspension after addition of SWE1 improved cell removal slightly (Fig. 1A). RE increased by $2-10 \%$ points at the lower clay concentrations, to up to $29 \%$, essentially increasing RE by a factor of 2.5 relative to addition without mixing. The highest RE observed was $49 \pm 5 \%$ with $0.50 \mathrm{~g} / \mathrm{L}$ of SWE1.

Comparable improvements were also observed when 5 ppm of PAC was used (without mixing), especially when clay concentration was $0.25 \mathrm{~g} / \mathrm{L}$ (Fig. 1A). However, the most dramatic improvement in RE was found when PAC was added to lower clay concentrations. Cell removal increased to $>25 \%$ between 0.025 and $0.50 \mathrm{~g} / \mathrm{L}$ of SWE1 when PAC was added, compared with clay alone. Small but insignificant increases in RE were found when PAC was combined with SWE2 and SWE3. Based on these data, SWE1 with $5 \mathrm{ppm}$ of PAC were tested further.

\subsection{Nutrient-limited cultures}

There were significant differences in RE among $P$. parvum grown in three nutrient conditions, and treated with SWE1 and PAC (Fig. 2A). The greatest 
(A)

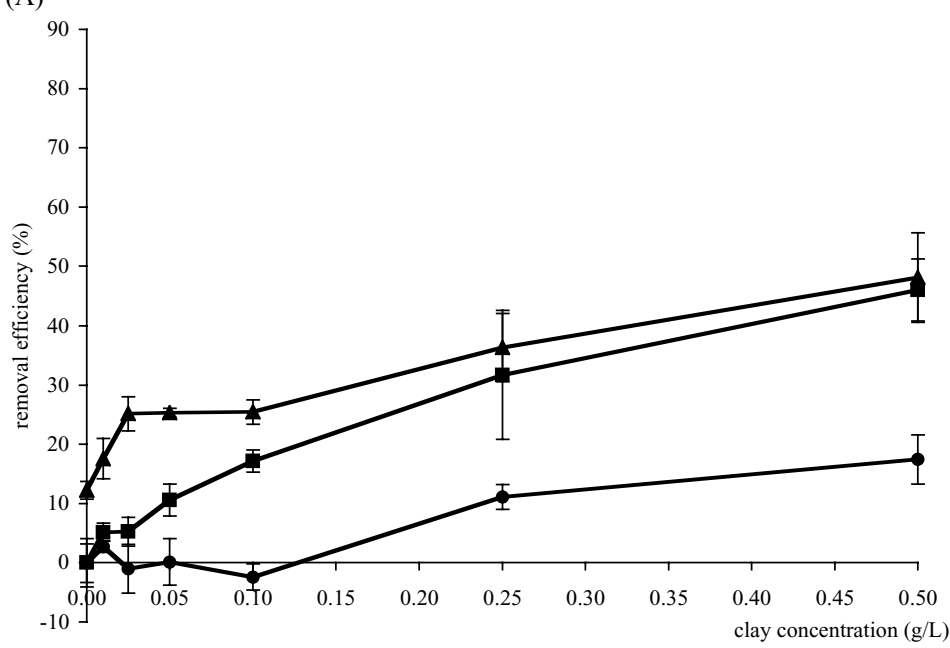

(C)

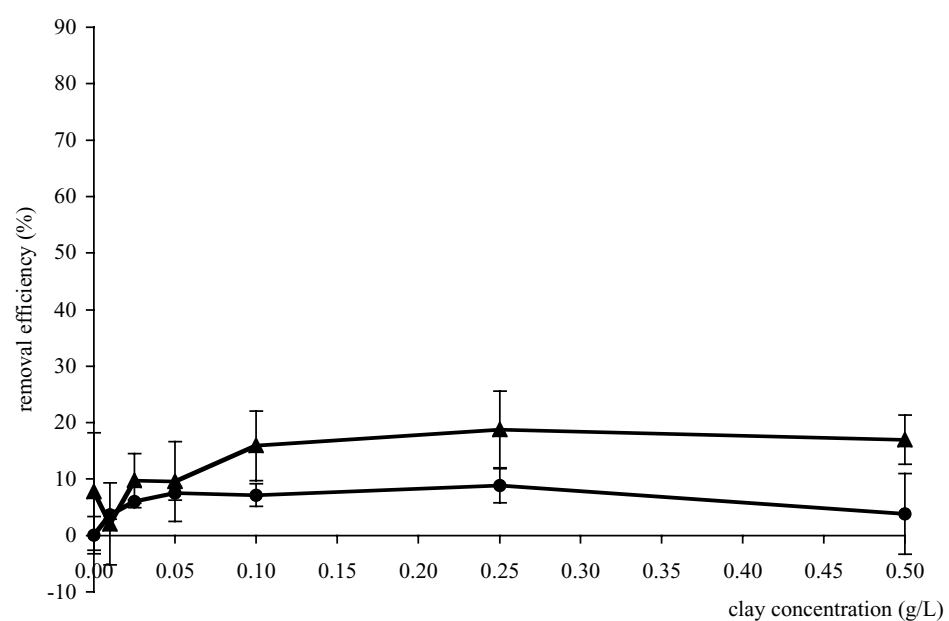

(B)

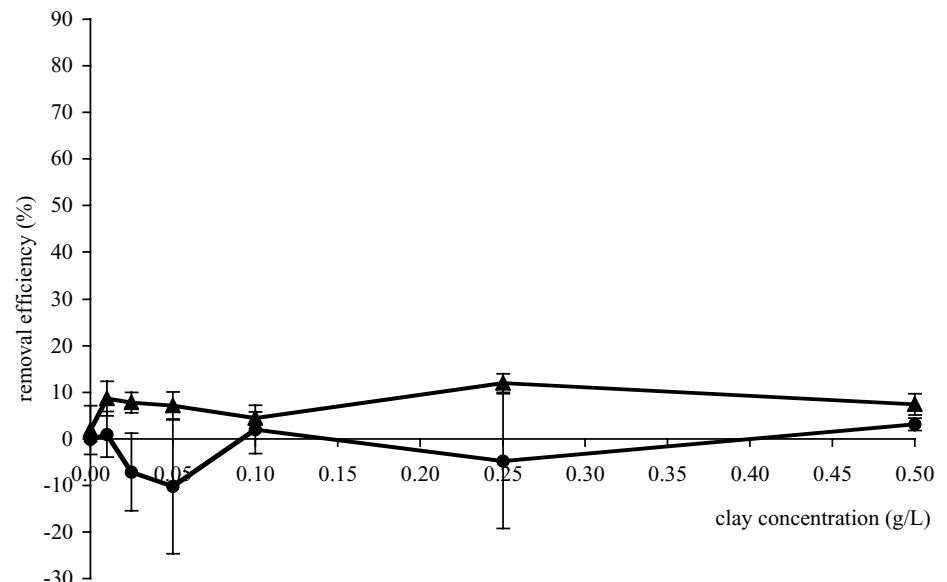

(D)

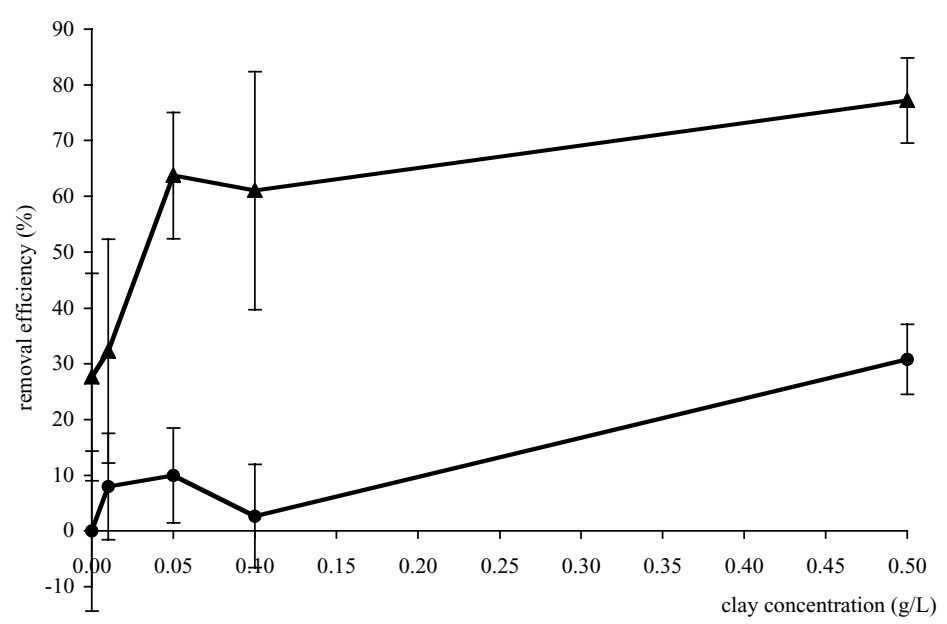

Fig. 1. Removal efficiency of Prymensium parvum with Swedish clays, following direct dispersal without mixing ( $)$, with brief mixing ( $\mathbf{\square})$, and the addition of 5 ppm polyaluminum chloride (PAC, $\mathbf{\Delta}$ ). (A) SWE1 dry bentonite. (B) SWE2 kaolinite. (C) SWE3 illite. (D) SWE4 wet bentonite. 
A. SWE1 dry bentonite

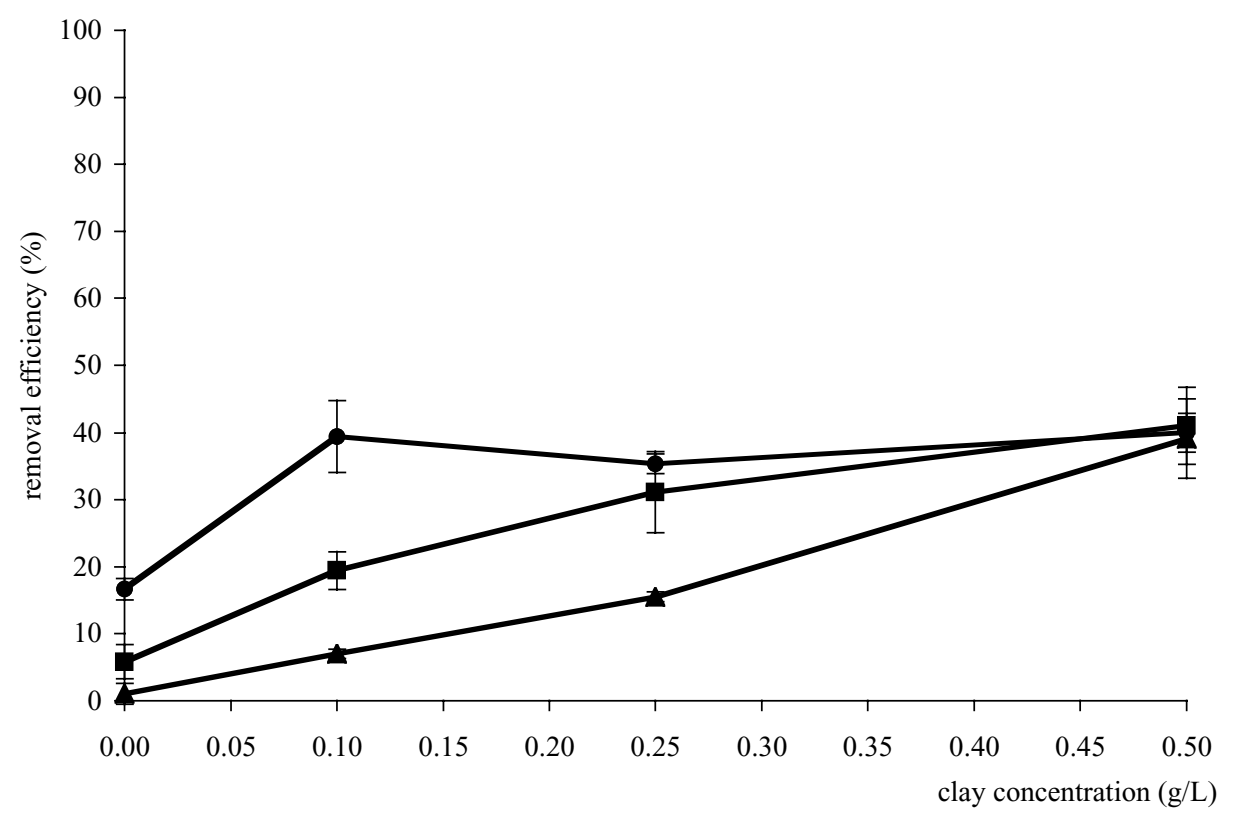

B. SWE4 wet bentonite

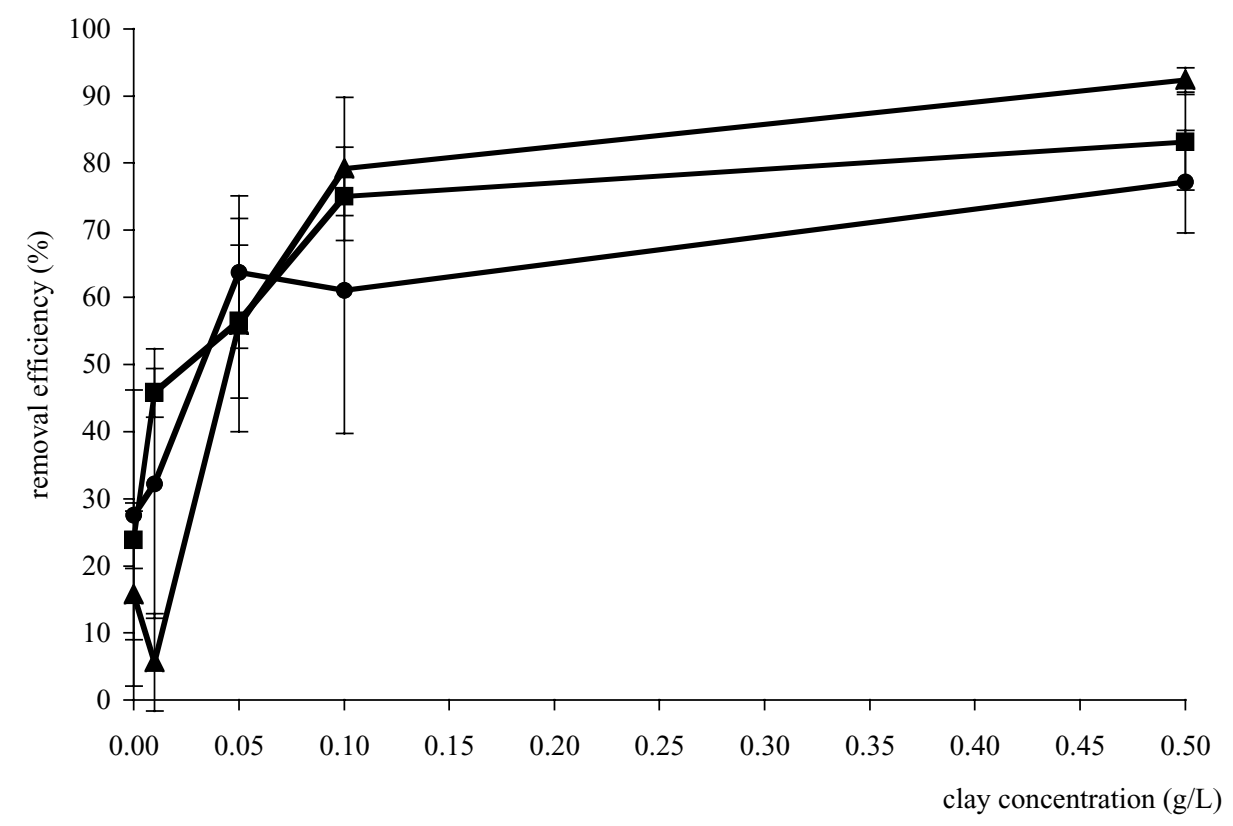

Fig. 2. Removal of Prymnesium parvum grown under NP-replete ( $)$, N-limited $(\boldsymbol{\square})$ and P-limited ( $\mathbf{\Delta})$ conditions, with two Swedish clays: (A) SWE1 dry bentonite combined with $5 \mathrm{ppm}$ of polyaluminum chloride (PAC). (B) SWE4 wet bentonite combined with 5 ppm of PAC. 
(A) NP-replete

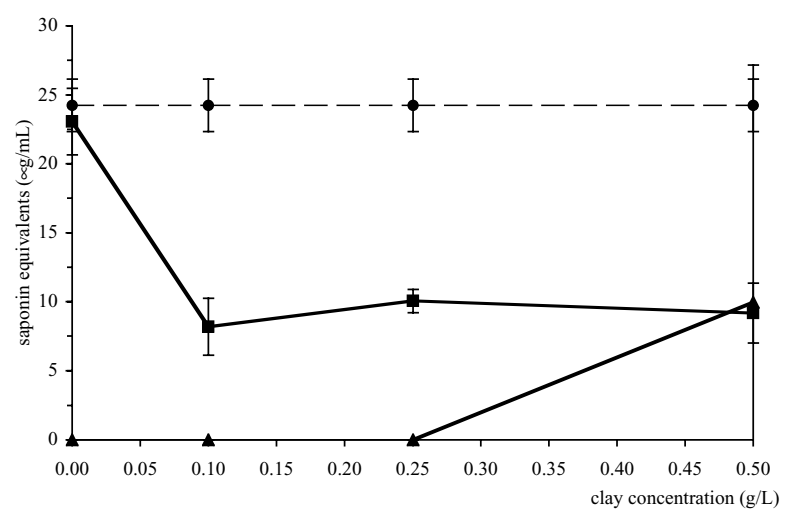

(B) N-limited

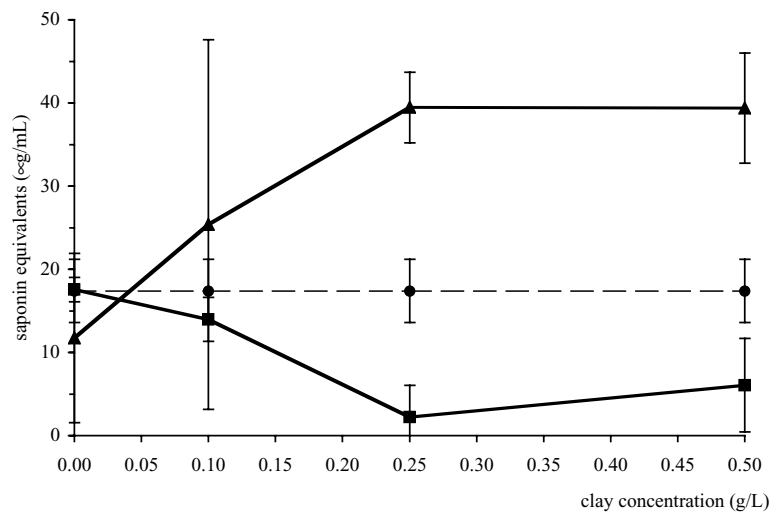

(C) P-limited

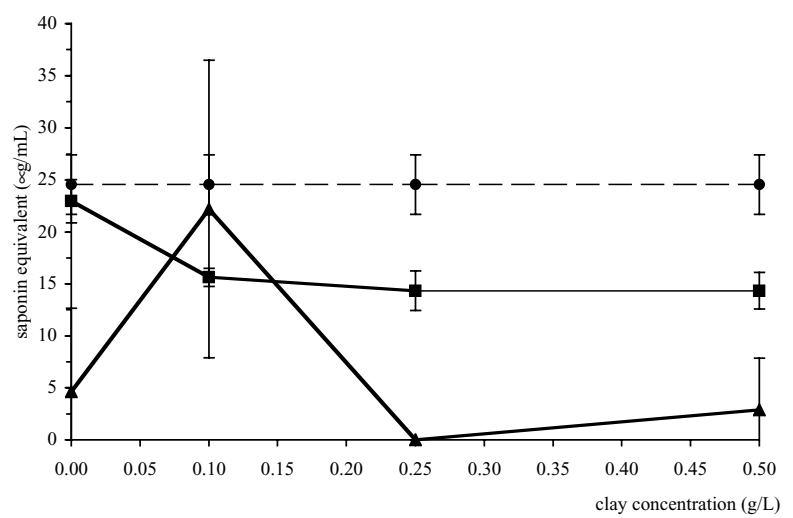

(D) NP-replete

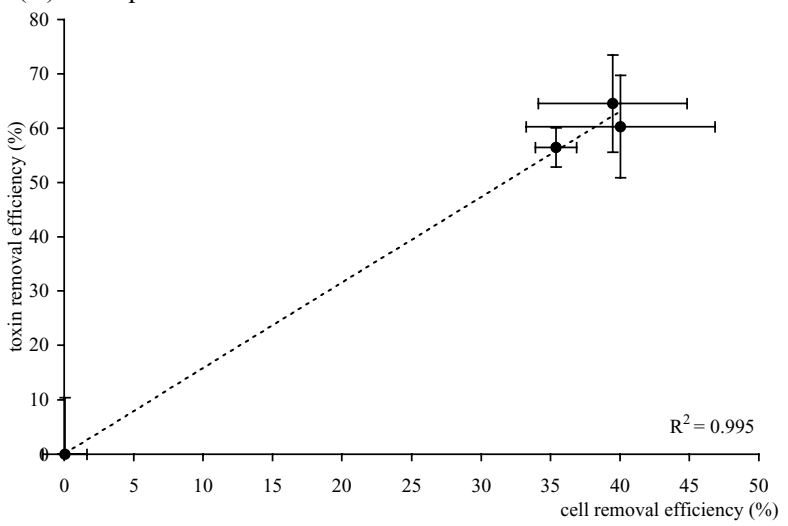

(E) N-limited

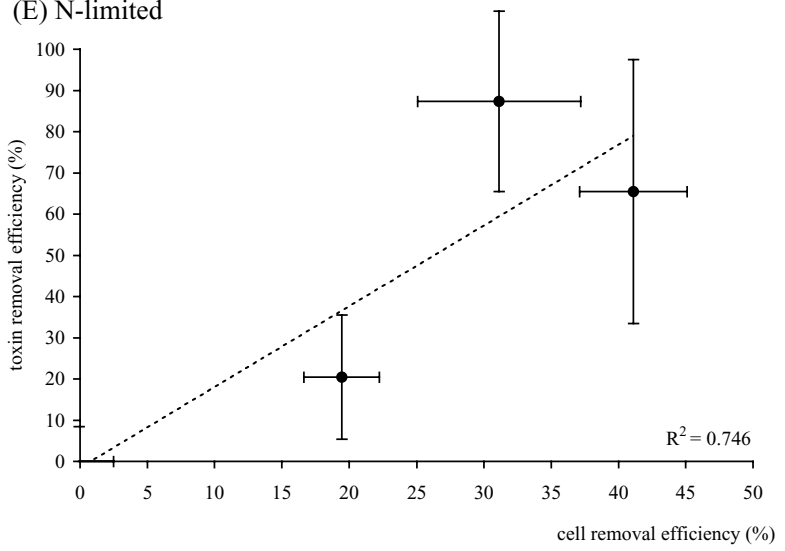

(F) P-limited

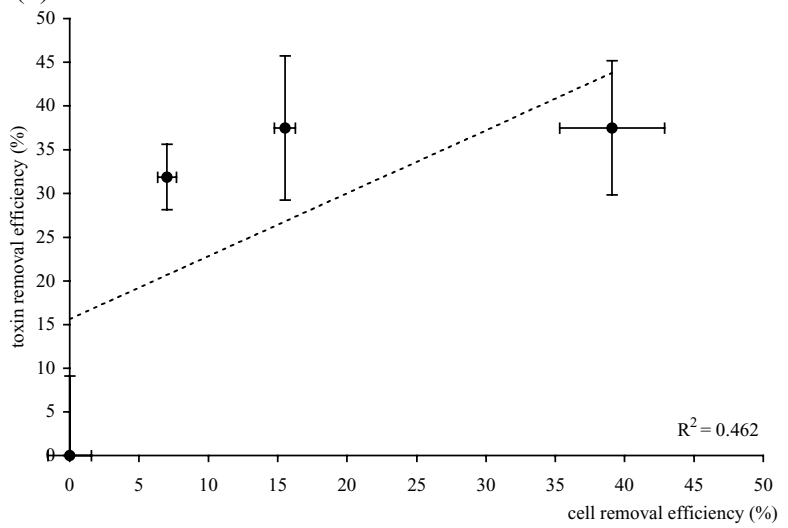

Fig. 3. Toxin removal experiments following SWE1 treatment, with 5 ppm polyaluminum chloride (PAC) added. (A-C) Toxin concentration before and after treatment in the supernatant and pellet: (A) NP-replete, (B) N-limited and (C) P-limited. (O), Initial culture toxicity; ( $\square$ ), supernatant toxicity after $2.5 \mathrm{~h},(\boldsymbol{\Delta})$, clay-cell pellet toxicity after $2.5 \mathrm{~h}$. (D-F) Comparison of cell removal efficiency with toxin removal efficiency: (D) NP-replete, (E) N-limited and (F) P-limited. 
differences were found at $0.25 \mathrm{~g} / \mathrm{L}$. Cells grown under nutrient replete conditions were removed in greater numbers, followed by $\mathrm{N}$-limited then P-limited cultures. This was most evident at $0.10 \mathrm{~g} / \mathrm{L}$ of SWE1. REs converged at ca. $40 \%$ for all cultures when clay concentration reached $0.50 \mathrm{~g} / \mathrm{L}$.

\subsection{Toxicity}

Starting with nutrient-replete cultures, the toxicity of the supernatant decreased following SWE1 and PAC treatment (Fig. 3A). Toxicity dropped from $24.2 \pm 1.9 \mu \mathrm{g} / \mathrm{mL}$ at the start of the experiment to an average of $9.2 \mu \mathrm{g} / \mathrm{mL}$ after clay treatment $(0.10-0.50 \mathrm{~g} / \mathrm{L})$, representing an average $60 \%$ toxin RE. Cell RE coincided well with toxin RE from the supernatant $\left(r^{2}=0.995\right.$, Fig. 3D), although cell RE averaged only $38 \%$ across the clay treatments. Interestingly, the loss of toxicity from the supernatant was not detected in the pellet in all of the treatments. Between 21 and $66 \%$ of the toxicity cannot be accounted in the mass balance between supernatant and pellet.
Treating N-limited cultures, toxicity in the supernatant also dropped from $17.4 \pm 3.8 \mu \mathrm{g} / \mathrm{mL}$ initially to between 14 and $2 \mu \mathrm{g} / \mathrm{mL}$ (Fig. 3B), depending on clay loading. This represented a toxin RE of between 21 and $87 \%$. However, the toxicity in the pellet increased dramatically following treatment, yielding values even higher than the initial toxicity of the N-limited culture (Fig. 3B). Here, the mass balance showed that total toxicity increased after clay treatment. Cell RE was moderately correlated to toxin removal $\left(r^{2}=0.746\right.$; Fig. 3E).

Finally, toxicity in the supernatant decreased in P-limited cultures treated with clay, from $24.6 \pm$ $2.9 \mu \mathrm{g} / \mathrm{mL}$ to an average of $14.8 \mu \mathrm{g} / \mathrm{mL}-\mathrm{a}$ toxin $\mathrm{RE}$ of $36 \%$ across the clay concentrations (Fig. 3C). At $0.10 \mathrm{~g} / \mathrm{L}$, the toxicity in the supernatant and pellet combined exceeded the initial conditions, but deficits were found at 0.25 and $0.50 \mathrm{~g} / \mathrm{L}$. There was no correspondence between cell removal and toxin removal $\left(r^{2}=0.462\right.$; Fig. 3F). Cell removal increased linearly with increasing clay concentration, while toxin removal increased hyperbolically with clay concentration.

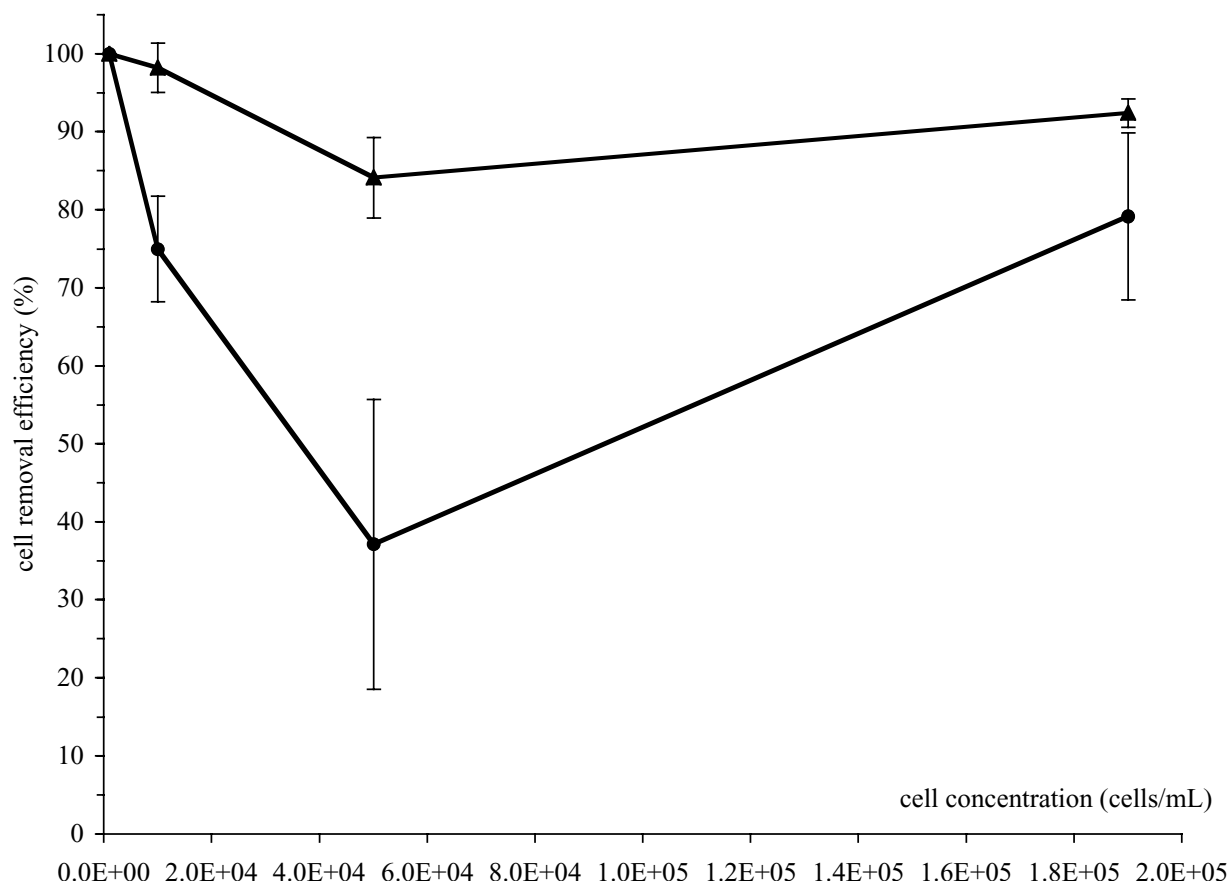

Fig. 4. Removal efficiency of Prymnesium parvum at varying cell concentrations with SWE4 and 5 ppm polyaluminum chloride (PAC), without mixing. Cultures were grown under P-limited conditions. $(\mathbf{O}), 0.10 \mathrm{~g} / \mathrm{L},(\mathbf{\Delta}), 0.50 \mathrm{~g} / \mathrm{L}$. 


\subsection{SWE4 wet bentonite}

The removal ability of SWE4 alone was only slightly better than that of SWE1 and the other two minerals (Fig. 1D). Nevertheless, SWE4 at $0.50 \mathrm{~g} / \mathrm{L}$ yielded the highest RE (at $31 \pm 6 \%$ ) among all of the samples tested in this study. Furthermore, there was a significant increase in RE when PAC was added to SWE4. At $0.05 \mathrm{~g} / \mathrm{L}$ of SWE4, for example, RE went from $10 \%$ without PAC to $64 \%$ with PAC. As clay concentration increased to $0.50 \mathrm{~g} / \mathrm{L}$, RE remained at this level or increased to $77 \%$ when PAC was used. Similarly, the removal of N- and P-limited cells with PAC-treated SWE4 was comparably high relative to NP-replete cells (Fig. 2B). Although the differences among the REs were not significant, the pattern of removal was slightly different from that of SWE1 (Fig. 2A). With SWE4, P-limited cells were removed more readily than $\mathrm{N}$-limited cells, followed by NP-replete cultures.

Lastly, the RE of P-limited $P$. parvum with PAC-treated SWE4 varied with the cell concentration (Fig. 4). Interestingly, RE peaked when cell concentration was the lowest $\left(100 \%\right.$ at $1 \times 10^{3}$ cells $\left./ \mathrm{mL}\right)$ and the highest (79 and $92 \%$ at $1 \times 10^{5}$ cells $/ \mathrm{mL}$, when clay concentrations were 0.10 and $0.50 \mathrm{~g} / \mathrm{L}$, respectively). RE dipped at the two intermediate cell concentrations (i.e. $1-5 \times 10^{4}$ cells $/ \mathrm{mL}$ ), although the value was higher at $0.50 \mathrm{~g} / \mathrm{L}$ than at $0.10 \mathrm{~g} / \mathrm{L}$ of clay. These experiments with SWE4 provided the highest removal values in this study.

\section{Discussion}

Our results showed that $P$. parvum was not removed efficiently $(<30 \%)$ by the three incinerated clays examined in this study (SWE1 bentonite, SWE2 kaolinite and SWE3 illite). In fact, the use of SWE2 produced mainly negative removal efficiencies, which has been interpreted as a "stabilization" of the cell culture, resulting in smaller cell loss due to sinking, relative to the clay-free controls (Sengco et al., 2001). In other words, the use of this clay kept the organisms suspended longer, instead of promoting their removal by flocculation and sinking.

According to our prediction, we did observe that bentonite had the best removal ability, but the mag- nitude of cell removal was far less than that of other HAB species removed with bentonites, montmorillonites, or montmorillonite-rich sediments (e.g. phosphatic clays) (e.g. RE $>90 \%$ for K. brevis, $>80 \%$ for Heterosigma akashiwo). These results are consistent with the low REs observed when smaller algal cells are treated with clays (e.g. A. anophagefferens (Sengco et al., 2001; Yu et al., in press) and Synechococcus sp. (Sengco, 2001)). As we predicted, kaolinite was the least effective, while illite was in between kaolinite and bentonite. Hence, the clays can be ordered in the following way from high to low removal ability: bentonite $($ SWE1) > illite (SWE3) > kaolinite (SWE2).

Hagström and Granéli (in press) found that $P$. parvum removal can be achieved at higher clay concentration and longer incubation times with the bentonite-rich Florida phosphatic clays. Particle concentration is another important factor in flocculation rates, along with particle size and charge (Yu et al., 1994). Moreover, Yu et al. (in press) found that prolonging the time for flocculation and settling to 7 days in the laboratory produced high removals of the $2-\mu \mathrm{m}$ cells of A. anophagefferens. Although additional clay amounts and longer incubations can be tested, we chose not to do so in this study, because we did not believe these to be reasonable conditions for treatments in natural waters. For instance, clay treatment would be undesirable if concentrations exceeded $0.50 \mathrm{~g} / \mathrm{L}$ due to potential environmental issues and cost of treatment, or if flocculation required several hours to take effect, as no water column would be static for such a length of time in nature.

Mixing the clay-cell suspension after clay addition yielded some improvement in cell removal, which had been shown to increase removal of other tiny species like A. anophagefferens (Sengco et al., 2001; Yu et al., in press) and the marine cyanobacterium, Synechococcus sp. (Sengco and Anderson, submitted). Therefore, part of the reason these clays were so ineffective may relate to the size of the species being targetted. The authors above proposed that the improvement in cell removal due to mixing was the result of higher collision rates between algal and clay particles, leading to higher flocculation rates, and the minimization of a process called "hydrodynamic retardation", a phenomenon wherein interparticle contacts are decreased due to the inability of smaller particles (e.g. cells) to approach and overcome the hydrodynamic forces 
generated by the flowing layer of water displaced by a much larger particle (e.g. clay floc) as it settles. By briefly mixing the suspension, the clay particles would be dispersed throughout the medium, which minimizes the formation of large clay-clay aggregates near the surface, while larger aggregates already formed would be broken up and redistributed within the entire suspension. From a practical standpoint, however, mixing and over-turning the suspension may be feasible under laboratory conditions, where volumes are small, but it will be difficult to transfer this approach to larger scales or field conditions wherein vigorous mixing of the water column would be impossible. Therefore, this experiment helped to elucidate the factors important in the removal processes, but not to indicate a practical strategy.

We found some improvement in P. parvum removal when PAC was added to the culture before SWE1 addition, but not with SWE2 and SWE3. We achieved 49\% RE with SWE1 and PAC. This is consistent with earlier work by Yu et al. (1994) and Sengco et al. (2001), who proposed that the enhancement of cell removal by PAC was due to the increase in the adhesiveness of clay (i.e. stickiness) towards the algae. PAC is a chemical flocculant commonly used in water treatment to remove fine suspended particles by inducing flocculation, without the dramatic $\mathrm{pH}$ shifts that occur when traditional flocculants like alum are used. Another advantage of PAC is its use in potable water treatment and low toxicity to humans and fish. Therefore, this substance would appear to be an acceptable additive to clay treatment for bloom control.

Results also showed that the physiological state of $P$. parvum can influence its RE with clay. With $0.25 \mathrm{~g} / \mathrm{L}$ of SWE1 and 5 ppm of PAC, cells grown in NP-replete conditons were removed more readily than those in $\mathrm{N}$ - and P-limited conditions, but the REs converged for all three cultures when clay concentration reached $0.50 \mathrm{~g} / \mathrm{L}$. Hagström and Granéli (in press) showed similar results for $P$. parvum using phosphatic clay and PAC. We hypothesize that cell physiology or the level of nutrient stress may affect the ability of $P$. parvum to avoid or resist flocculation with clays. Healthy cells with sufficient nutrients may have enough energy to avoid clay particles or aggregates, or to escape the floc during descent or the clay-cell pellet after deposition. Nutrient-limited cells, on the other hand, may not have adequate energy to allow them to avoid or escape flocculation and settling. However, when the particle concentration becomes rather high, the probability of encountering clay particles increases and the chances of escaping decreases for cells, regardless of their physiological status. This hypothesis may have implications for how a diverse population under different levels of nturient stress would be affected by fine suspended sediments in nature. A bloom in the early to middle stages of development, when nutrients are still abundant, may be removed differently than a bloom closer to decline. However, cell concentration is also an important factor in the effectiveness of clay treatment for this species (see below).

The nutrient status of $P$. parvum may also be an important consideration on whether to use clays, with regards to the fate of toxins. Our results showed good correspondence between cell RE and toxin RE, especially with NP-replete cultures and N-limited cultures. However, we also found that the toxin concentration of N-limited cells in the pellet increased dramatically after $2.5 \mathrm{~h}$, to levels above the initial toxin concentration of the cells at the start of the experiment. This phenomenon was also described by Hagström and Granéli (in press). It has already been well-documented by several workers (e.g. Johansson and Graneli, 1999; Granéli and Johansson, 2001) that nutrient limitation increases the toxicity and allelopathic effects of $P$. parvum in culture. It has was further proposed by Hagström and Granéli (in review) that the potentially stressful handling and treatment of $P$. parvum with clays, especially during settling may induce toxin production. Therefore, there is a possibility that the toxicity in the sediment may increase substantially not only through the forced settling of $P$. parvum biomass, but through the increase in the total toxin concentration immediately after treatment. This should be considered carefully in evaluating this control strategy, especially the timing of treatment relative to the physiological condition of the bloom organisms. However, this effect was only observed with $\mathrm{N}$ stress, not with $\mathrm{P}$ stress or under NP-replete conditions. Moreover, there was poor correlation between cell and toxin removal efficiencies in P-limited cultures. There is no current explanation for this phenomenon.

When the three clay samples were first obtained and subsequently tested, we did not know that they had been incinerated as required by EU regulations, to 
eliminate organisms and chemical contaminants prior to export. In this light, the low REs of P. parvum may be partially explained. Earlier experiments showed that Florida phosphatic clay loses its removal ability when dried, even after prolonged reconstitution and wetting with water (Sengco, unpublished data). This may be due to the collapse of the layered montmorillonite structure, as interstitial water molecules are driven out. Once collapsed, it becomes more difficult to re-introduce the lost moisture, leading to poor wetting and loss of mineral expansion. As a result, RE against K. brevis dropped from $>90$ to $<40 \%$ (Sengco, unpublished data).

To test whether incineration reduced the clay's ability to remove the bloom, we tested a wet, unprocessed version of SWE1 bentonite. However, SWE4 was only slightly better than SWE1, suggesting that the drying and incineration process may not be the primary factor affecting removal, but rather the size of the species being targeted. After all the results are compared, the most effective clay treatment, involved SWE4 wet bentonite combined with $5 \mathrm{ppm}$ PAC, without mixing. There were slight, but insignificant differences in the removal of NP-replete, N-limited and P-limited cultures with this clay. Based on these results, SWE4 with PAC was the most effective mineral sample against $P$. parvum.

Finally, the RE of P-limited $P$. parvum with PAC-treated SWE4 varied with cell concentration. For $0.10 \mathrm{~g} / \mathrm{L}$ of SWE4 (with PAC), cell removal decreased by half as the cell concentration increased by one order of magnitude, although RE decreased by $<1 \%$ when clay concentration increased to $0.50 \mathrm{~g} / \mathrm{L}$ over the same range of cell concentrations. Similar results were found by Hagström and Granéli (in press), who tested NP-replete cultures treated with phosphatic clays. Interestingly, RE increased again as cell concentration increased even more, which suggests that by increasing the total number of particles in the system (i.e. clays and cells), the overall flocculation rates would also increase, and proportionally more cells would be removed.

It should be noted that these experiments were conducted with water adjusted to salinity of 26 consistently. Although P. parvum can be found under these conditions, $P$. parvum blooms in the Baltic Sea grow in much lower salinities. The ionic strength of the media and the dominant cation species both affect the rate of clay flocculation, and by extension, clay-cell flocculation. For $P$. piscicida treated with clay, for example, cell removal decreased by a factor of 2 as salinity increased (Sengco, unpublished data). Yu et al. (in press) showed that preparing the clay slurry with freshwater, instead of seawater (salinity $=30$ ) produced higher removal of A. anophagefferens, using the same amount and type of clay. Therefore, additional work should be conducted to examine the effect of salinity on $P$. parvum removal by clay to aid in evaluating this control method.

Ultimately, it should be noted that the algal species tested thus far in the literature have displayed a wide range of removal efficiencies with a given clay mineral. The propensity of a species to be removed by clay cannot be ascertained simply by the physical (i.e. size, shape, and structure) and chemical (e.g. surface charge) properties of the minerals, cells and medium, using models constructed from colloidal flocculation theory (Sengco, 2001), even though many attempts have been made (e.g. Yu et al., 1994). The number of interacting, synergistic factors render the clay-cell system too complex for existing models. In some cases, predictions have agreed with the empirical results, but in the end, each clay-algae system appears to be unique, and must be addressed individually. Moreover, some biological factors have not been fully considered in flocculation models, such as variable adaptive responses of a given species to the presence of suspended matter. For example, Burkholder (1992) described species of Gymnodinium that release copious amounts of mucus-like organic matter in the presence of high silt and clay as a defense mechanism from direct contact with the minerals. Later, the organisms escaped from the organic sheath and resumed vegetative growth. By contrast, $K$. brevis are readily removed by various clays, and do not appear to have this defense mechanism. Overall, these studies demonstrated that clay flocculation can be effective at removing $P$. parvum and its toxins only under certain treatment conditions with respect to cell concentration, clay concentration and physiological status.

\section{Acknowledgements}

We wish to thank the members of the FATE working group for their help in this project, especially 
Dr. Catherine Legrand for coordinating the research groups, and Dr. Kalle Olli and members of his lab who performed daily Coulter counter calibrations at Tvärminne. We are also grateful to the staff, scientists and colleagues at the Tvärminne Zoological Station in Finland for their technical and logistical contributions in support of this study. At the University of Kalmar in Sweden, we appreciate the help of Christina Esplund-Lindquist and other members of the Department of Biology and Environmental Science. This work was supported by the European Commission (Research Directorate General-Environment Programme-Marine Ecosystems) through the FATE project "Transfer and Fate of Harmful Algal Bloom (HAB) Toxins in European Marine Waters" (contract EVK3-CT01-00055). FATE is part of the EC EUROHAB cluster. Some additional support was provided by the Cove Point Foundation and the Sholley Foundation. This is WHOI contribution number 11125 .

\section{References}

Archambault, M.-C., Grant, J., Bricelj, V.M., 2003. Removal efficiency of the dinoflagellate Heterocapsa triquetra by phosphatic clay and implications for the mitigation of harmful algal blooms. Mar. Ecol. Prog. Ser. 253, 97-109.

Avnimelech, Y., Troeger, B.W., Reed, L.W., 1982. Mutual flocculation of algae and clay: evidence and implication. Science 216 (4541), 63-65.

Burkholder, J.M., 1992. Phytoplankton and episodic suspended sediment loading: phosphate partitioning and mechanisms for survival. Limnol. Oceanogr. 37 (5), 974-988.

Edvardsen, B., Paasche, E., 1998. Bloom dynamics and physiology of Prymnesium and Chrysochromulina, In: Anderson, D.M., Cembella, A.D., Hallegraeff, G.M. (Eds.), Physiological Ecology of Harmful Algal Blooms, Springer-Verlag, Berlin, pp. 193-208.

Fistarol, G.O., Legrand, C., Granéli, E., 2003. Allelopathic effect of Prymnesium parvum on a natural plankton community. Mar. Ecol. Prog. Ser. 255, 115-125.

Granéli, E., Johansson, N., 2001. Nitrogen or phosphorus deficiency increases allelopathy in Prymnesium parvum, In: Hallegraeff, G.M., Blackburn, S.I., Bolch, C.J., Lewis, R.J. (Eds.), Harmful Algal Blooms 2000, Intergov. Oceanografic Commission of UNESCO, pp. 328-331.

Granéli, E., Johansson, N., 2003a. Effects of the toxic haptophyte Prymnesium parvum on the survival and feeding of a ciliate: the influence of different nutrient conditions. Mar. Ecol. Prog. Ser. $254,49-56$

Granéli, E., Johansson, N., 2003b. Increase in the production of allelopathic substances by Prymnesium parvum cells grown under N- or P- deficient conditions. Harmful Algae 2, 135.
Grim, R.E., 1953. Clay Mineralogy, McGraw-Hill Book Co., Inc., New York.

Hagström, J.A., Granéli, E., (in press). Efficiency of phosphatic clay in removing Prymnesium parvum (Haptophyceae) at different cell densities and intracellular nitrogen and phosphorus content, and the effect on toxicity of the algae. Harmful Algae.

Holmquist, E., Willém, T., 1993. Fish mortality caused by Prymnesium parvum. Vatten 49, 110-115.

Igarashi, T., Satake, M., Yasumoto, T., 1996. Prymnesin-2: a potent ichtyotoxic and haemolytic glycoside isolated from the red tide algae Prymnesium parvum. J. Am. Chem. Soc. 118, 479-480.

Johansson, N., Graneli, E., 1999. Influence of different nutrient conditions on cell density, chemical composition and toxicity of Prymnesium parvum (Haptophyta) in semi-continuous cultures. J. Exp. Mar. Biol. Ecol. 239, 243-258.

Komarovsky, B., 1951. Some characteristic water-blooms in Lake Tiberias and fish ponds in the Jordan Valley. Ver. Int. Ver. Theor. Angew. Limnol. 11, 219-223.

Lindholm, T., Öhman, P., Kurki-Helasmo, K., Kincaid, B., Meriluoto, J., 1999. Toxic algae and fish mortality in a brackish water lake in Åland, SW Finland. Hydrobiology 397, 109-120.

Moestrup, Ø., 1994. Economic aspects: blooms, nuiscance species and toxins, In: Green, J.C., Leadbeater, B.S.C. (Eds.), The Haptophyte Algae, Clarendon Press, Oxford, pp. 265-285.

Na, G., Choi, W., Chun, Y., 1996. A study on red-tide control with loess suspension. J. Aquacult. 9 (3), 239-245.

Rensel, J.E., Anderson, D.M., (in press). Effects of phosphatic clay dispersal at a salmon farming site to control harmful algal blooms in Puget Sound, Washington, In: Proceedings of the Xth International Conference on Harmful Algae, St. Pete's Beach, Florida.

Sengco, M.R., Li, A., Tugend, K., Kulis, D., Anderson, D.M., 2001. Removal of red- and brown-tide cells using clay flocculation. I. Laboratory culture experiments with Gymnodinium breve and Aureococcus anophagefferens. Mar. Ecol. Prog. Ser. 210, 4153.

Sengco, M.R., 2001. The aggregation of clay minerals and marine microalgal cells: physicochemical theory and implications for controlling harmful algal blooms. Doctoral dissertation, Massachusetts Institute of Technology/Woods Hole Oceanographic Institution Joint Program in Oceanography.

Sengco, M.R., Anderson, D.M., (submitted). Differential removal of marine algal species by clay aggregation: effect of cell concentration, size and swimming rate. Mar. Ecol. Progress Ser., submitted for publication.

Shirota, A., 1989. Red tide problem and countermeasures (2). Int. J. Aquat. Fish. Technol. 1, 195-223.

Simonsen, S., Moestrup, Ø., 1997. Toxicity test in eight species of Chrysochromulina (Haptophyta). Can. J. Bot. 75, 129-136.

Soballe, D.M., Threlkeld, S.T., 1988. Algal-clay flocculation in turbid waters: variations due to algal and mineral differences. Verh. Internat. Verein. Limnol. 23, 750-754.

Swartzen-Allen, S.L., Matijevic, E., 1974. Surface and colloid chemistry of clays. Chem. Rev. 74 (3), 385-400.

Tillmann, U., 2003. Kill and eat your predator: a winning strategy of the planktonic flagellate Prymnesium parvum. Aquat. Microb. Ecol. 32, 73-84. 
Valkanov, A., 1964. Untersuchungen über Prymnesium parvum Carter und seine toxische Einwirkung auf die Wasserorganismen. Kiel Meeresforsch. 20, 65-81.

Yu, Z., Zou, J., Ma, X., 1994. Application of clays to removal of red tide organisms. I. Coagulation of red tide organisms with clays. Chin. J. Oceanol. Limnol. 12 (3), 193-200.
Yu, Z., Sengco, M.R., Anderson, D.M., (in press). Flocculation and removal of the brown tide organism, Aureococcus anophagefferens (Chrysophyceae), using clays. In: Proceedings of the 10th International Conference on Harmful Algae; J. Appl. Phycol. 